\title{
Edukasi dan Pemeriksaan Darah dalam Rangka Pencegahan Penyakit Tidak Menular
}

\author{
Margareta Haiti ${ }^{1}$, Novita Anggraini'2, Victoria Ire Tominik ${ }^{3}$ \\ Fakultas Ilmu Kesehatan UNIKA Musi Charitas, Jl.Kol.H.Barlian KM7 Palembang \\ Email : ${ }^{1}$ margarethahaiti@ukmc.ac.id, 2novitaanggraini@ukmc.ac.id, \\ 3victoriaire@ukmc.ac.id
}

\begin{abstract}
Non-communicable diseases (PTM) are a group of chronic diseases, not contagious and can attack all organs of the body, so PTM has a large impact both in terms of morbidity and mortality on public health. Based on information from community leaders from the Sukarami Village, many people experience hypertension, diabetes, rheumatism or pain in the joints so that people are very much expecting help from health workers to provide counseling and health checks in order to prevent disease or attempt to find the cause of the disease. Residents who attended the PKM activities amounted to 138 people. The results of glucose level examination obtained a normal category of 111 people, Prediabetes category as many as 21 people and diabetes category as many as 6 people while the examination of uric acid levels obtained normal results as many as 101 people, abnormal category as many as 36 people and not examined as many as 1 person but the results the measurement of people's blood pressure that came showed 67 (48.6\%) more than normal meaning that quite a lot of people tended to suffer from hypertension. It was concluded that community awareness of the importance of checking blood sugar and gout, especially for those aged $>40$ years, still needs to be improved through regular education and blood tests to prevent (preventive efforts), especially non-communicable diseases.
\end{abstract}

Keywords: Non-communicable diseases, education, preventive efforts

\section{Pendahuluan}

Penyakit Tidak Menular (PTM) adalah sekelompok penyakit kronis, tidak menular, dimana diagosis dan terapinya pada umumnya lama dan mahal.PTM sendiri dapat terkena pada semua organ, sehingga jenis penyakitnya juga banyak sekali.Berkaitan dengan itu, pendekatan yang digunakan adalah pendekatan kesehatan masyarakat (public health).Untuk itu perhatian difokuskan pada PTM yang mempunyai dampat besar baik dari segi morbiditas maupun mortaliasnya sehingga menjadi isu kesehatan masyarakat (public health issue). Permasalahan yang muncul dalam upaya pengendalian penyakit tidak menular antara lain perilaku masyarakat yang 
berisiko PTM karena keterbatasan media dan metode diskusi. Media edukasi yang tersedia untuk mendukung Prilaku Hidup Bersih dan Sehat (PHBS) masih terbatas pada media cetak. Fasilitas kesehatan maupun di saran publik dan sekolah dibutuhkan media edukasi kesehatan yang lebih bervariasi. ${ }^{1}$

Penanggulangan Penyakit Tidak Menular merupakan upaya kesehatan yang mengutamakan aspek promotif dan preventif tanpa mengesampingkan aspek kuratif dan rehabilitatif guna menurunkan angka kesakitan, kecacatan, dan kematian yang komprehensif, efektif, efisien, dan berkelanjutan.Surveilans PTM adalah kegiatan pengamatan yang sistematis dan terus menerus terhadap data dan informasi tentang kejadian faktor risiko dan PTM serta kondisi yang mempengaruhi terjadinya peningkatan, guna mengarahkan tindakan penanggulangan secara efektif dan efisien dengan memberikan informasi. ${ }^{2}$

Penyakit Tidak Menular (PTM) merupakan penyakit yang sering kali tidak terdeteksi karena tidak bergejala dan tidak ada keluhan.Biasanya ditemukan dalam tahap lanjut sehingga sulit disembuhkan dan berakhir dengan kecacatan atau kematian dini. Keadaan ini menimbulkan beban pembiayaan yang besar bagi penderita, keluarga dan negara. PTM ini dapat dicegah melalui pengendalian faktor risiko, yaitu merokok, kurang aktifitas fisik, diet yang tidak sehat, dan konsumsi alkohol. Peningkatan kesadaran, dan kepedulian masyarakat terhadap faktor risiko PTM sangat penting dalam pengendalian PTM. ${ }^{3}$

Pola hidup modern telah mengubah sikap dan prilaku manusia, termasuk pola makan, merokok, konsumsi alkohol serta obat-obatan sebagai gaya hidup sehingga penderita penyakit degeratif (penyakit penurunan fungsi organ tubuh) semaikn meningkat dan mengancam

\footnotetext{
${ }^{1}$ Kementerian Kesehatan RI, (2017), Pengendalian Penyakit Menular, Direktorat Pengawasan dan pencegahan Penyakit Tidak Menular, Jakarta

2Peraturan Menteri Kesehatan, 2015, Penanggulangan Penyakit Tidak Menular, Nomor 1775 tahun 2015

${ }^{3}$ Dina Zakiyyatul Fuadah dan Naning Furi Rahayu, (2018), Pemanfaatan Pos Pembinaan Terpadu (POSBINDU) Penyakit Tidak Menular (PTM) Pada Penderita Hipertensi, Jurnal Ners dan Kebidanan, Volume 5, Nomor 1, April 2018. DOI: 10.26699/jnk.v5i1.ART.p020-028
} 
kehidupan. 4

Penyakit-penyakit tidak menular yang bersifat kronis dan degeneratif sebagai penyebab kematian mulai menggeser kedudukan dari penyakitpenyakit infeksi.Penyakit tidak menular mulai meningkat bersama dengan life-span (pola hidup) pada masyarakat. Life-span meningkat karena adanya perubahan-perubahan didalam kondisi sosial ekonomi, kondisi hygiene sanitasi, meningkatnya ilmu pengetahuan dan perubahan perilaku. ${ }^{5}$

Penyakit tidak menular merupakan salah satu masalah kesehatan yang menjadi perhatian nasional maupun global pada saat ini. Data WHO (2008) menunjukan bahwa dari 57 juta kematian yang terjadi, 36 juta atau hampir dua pertiganya disebabkan oleh Penyakit Tidak Menular. Di negara dengan tingkat ekonomi rendah sampai menengah, 29\% kematian yang terjadi pada penduduk berusia kurang dari 60 tahun disebabkan oleh PTM. Indonesia masih banyak masalah terkait kesehatan yaitu penyakit menular, kejadian re-emerging diseases dan new emerging diseases yang masih sering terjadi. Kejadian PTM cenderung meningkat dari waktu ke waktu. ${ }^{6}$

Insiden dan prevalensi PTM diperkirakanterjadi peningkatan secara cepat pada abad ke-21. Ini merupakan tantangan utama masalah kesehatan di masa yang akan datang.Pada tahun 2020 PTM akan menyebabkan 73\% kematian dan $60 \%$ seluruh kesakitan di dunia. ${ }^{7}$

Penyakit Tidak Menular (PTM) seperti kanker, jantung, DM, dan paru obstruktif kronik, serta penyakit lainnya diprediksi akan mengalami peningkatan yang signifikan pada tahun 2030, seiring dengan peningkatan resiko akibat perubahan gaya hidup, gangguan mental emosional dengan adanya perubahan lingkungan fisik dan perkembangan dunia semakin modern. Menurut hasil Riset Kesehatan Dasar (Riskesdas) tahun 2007 dan

${ }^{4}$ Nur, N.N., \& Warganegara, E. 2016. Faktor Risiko Perilaku Penyakit Tidak Menular. Jurnal Fakultas Kedokteran Universitas Lampung. vol. 5. no.2. pp 1-7

${ }^{5}$ Darmawan Armadi, (2016)

${ }^{6}$ Nur, N.N., \& Warganegara, E. 2016. Faktor Risiko Perilaku Penyakit Tidak Menular. Jurnal Fakultas Kedokteran Universitas Lampung. vol. 5. no.2. pp 1-7

${ }^{7}$ Dina Zakiyyatul Fuadah dan Naning Furi Rahayu, (2018), 
Survey Kesehatan Rumah Tangga (SKRT) tahun 1995 dan 2001, tampak bahwa selama 12 tahun (1995 - 2007) telah terjadi transisi epidemiologi dimana kematian karena PTM semakin meningkat, sedangkan kematian karena penyakit menular semakin menurun. Berdasarkan olahan laporan rumah sakit tahun 2009 dan 2010 gambaran ini juga terlihat sama, yaitu penyakit PTM merupakan penyebab utama kematian di rumah sakit. ${ }^{8}$

Wilayah Pasifik dan Asia Timur penyakit tidak menular merupakan 71,03 \% penyebab kematian pada tahun 2002 dan menimbulkan DALYS (Disability Adjusted Life Years) sebesar 46,90 \%. Bertdsarkan Riskesdas 2007 Di Indonesia proporsi angka kematian penyakit tidak menular meningkat dari 41,7 \% pada tahun 1995 menjadi 59,5 \% pada Tahun 2007. Tantangan lain yang dihadapi Indonesia adalah meningkatnya masalah yang berkaitan dengan bertambahnya usia lanjut yang menyebabkan beban pembiayaan kesehatan semakin meningkat. Sementara itu penderita penyakit tidak menular seperti penyakit jantung dan pembuluh darah tidak lagi mengenal kelompok status soosial ekonomi masyarakat yang diakibatkan perubahan gaya hidup yang tidak sehat dan faktor resiko penyakit tidak menular. ${ }^{9}$ Penyakit tidak menular dapat dicegah melalui berbagai upaya baik secara perorangan atau melalui kelompok-kelompok masyarakat.

\section{Metode}

Pada kegiatan pengabdian ini masyarakat di Kelurahan Sukarami Kecamatan Sukarame Kota Palembang dilakukan penyuluhan kesehatan tentang penyakit tidak menular dan pemetingnya pemeriksaan kesehatan seperti pemeriksaan kadar asam urat dalam darah. Masyarakat mau dilakukan pemeriksaan kadar asam urat dan bila didapatkan hasil pemeriksaan melebihi nilai rujukan maka diberikan penyuluhan khusus serta

\footnotetext{
${ }^{8}$ Kementerian Kesehatan RI, 2012, Buletin, Penyakit Tidak Menular, Semester II, Jakarta

${ }^{9}$ Rahajeng Ekowati, 2011
} 
dianjurkan untuk konsultasi ke dokter spesialis penyakit dalam.

Tahapan kegiatan pengabdian kepada masyarakat yaitu sebagai berikut:

1. Pembentukkan tim PKM

2. Pembuatan Proposal dan anggaran survey epidemiologi serta pemeriksaan kadar asam urat kepada masyarakat pada warga RT 26 RT 38 dan RT 40 Kelurahan Sukarami Kecamatan Sukarame Kota Palembang

3. Perizinan kegiatan PKM

4. Survey lapangan dan pendataan warga RT 26 RT 38 dan RT 40 Kelurahan Sukarami Kecamatan Sukarame Kota Palembang

5. Rapat koordinasi

6. Persiapan pemeriksaan dan pengiriman undangan kepada warga

7. Melakukan penyuluhan dan pemeriksaan kadar asam urat

8. Menyusun laporan kegiatan Pengabdian Kepada Masyarakat

Luaran pada pengabdian masyarakat ini yaitu Warga RT 26, RT 38 dan

RT 40 Kelurahan Sukarami Kecamatan Sukarame Kota Palembang mengetahui kadarasam urat dan memahami pentingnya skrining kadar asam urat dalam darah dalam upaya mencegah penyakit tidak menular.

\section{Hasil dan Diskusi}

\section{Hasil}

Kegiatan Pengabdian Kepada Masyarakat diadakan pada tanggal 28 April 2019 yang dihadiri warga masyarakat RT 26, RT 38 dan RT 40 Kelurahan Sukarami Kecamatan Sukarame Kota Palembang. Warga yang hadir berjumlah 138 orang terdiri dari 3 kategori yaitu umur $\leq 40$ tahun sebanyak 33 orang, umur $>40$ tahun sebanyak 99 orang, dan yang tidak tercatat sebanyak 6 orang. Persentase umur peserta pemeriksaan yang hadir, seperti tampak pada Tabel 1. berikut: 
Tabel 1. Jumlah dan Persentase Kepala Keluarga (KK)

\begin{tabular}{|c|c|c|c|c|c|c|c|c|}
\hline \multirow{2}{*}{ KK } & \multicolumn{9}{|c|}{ RT } \\
\cline { 2 - 9 } & \multicolumn{2}{|c|}{26} & \multicolumn{2}{|c|}{38} & \multicolumn{2}{|c|}{40} & \multicolumn{2}{|c|}{ Total } \\
\cline { 2 - 9 } & $\sum$ & $\%$ & $\sum$ & $\%$ & $\sum$ & $\%$ & $\sum$ & $\%$ \\
\hline Terdata & 78 & $25,66 \%$ & 79 & $25,99 \%$ & 80 & $26,32 \%$ & 237 & $77,96 \%$ \\
\hline Tidak & & & & & & & & \\
Terdata & 9 & $2,96 \%$ & 38 & $12,50 \%$ & 20 & $6,58 \%$ & 67 & $22,04 \%$ \\
\hline$\sum$ & 87 & $29 \%$ & 117 & $38,49 \%$ & 100 & $18,12 \%$ & 304 & $100 \%$ \\
\hline
\end{tabular}

Sumber: Data di lapangan, 2019

Pada Tabel 1. Jumlah Kepala Keluarga (KK) sebanyak 304 KK tetapi yang terdata berjumlah $237 \mathrm{KK}$ sedangkan yang tidak dapat didata sebanyak $67 \mathrm{KK}$.

Tabel 2. Jumlah dan Persentase Anggota Keluarga

\begin{tabular}{|c|c|c|c|c|c|c|c|c|}
\hline \multirow{2}{*}{ Anggota Keluarga } & \multicolumn{9}{|c|}{ RT } \\
\cline { 2 - 9 } & \multicolumn{2}{|c|}{26} & \multicolumn{2}{|c|}{38} & \multicolumn{2}{c|}{40} & \multicolumn{2}{c|}{ TOTAL } \\
\hline Laki-laki & 158 & $18,02 \%$ & 155 & $17,67 \%$ & 102 & $11,63 \%$ & 415 & $47,32 \%$ \\
\hline Perempuan & 128 & $14,60 \%$ & 153 & $17,45 \%$ & 181 & $20,64 \%$ & 462 & $52,68 \%$ \\
\hline$\sum$ & 286 & $32,61 \%$ & 308 & $35,12 \%$ & 283 & $32,27 \%$ & 877 & $100 \%$ \\
\hline
\end{tabular}

Sumber: Data di lapangan, 2019

Pada Tabel 2. Jumlah Anggota Keluarga (AK) sebanyak 877orang yang terdiri dari bayi, anak-anak, remaja, dewasa dan lansia. Warga yang hadir pada pelaksanaan kegiatan PKM berjumlah 138 orang, artinya masih perlu pendampingan untuk meningkatkan kesadaran masyarakat dalam menjaga pola hidup yang sehat dan pemeriksaan kesehatan secara berkala.

Tabel 3. Persentase Umur Peserta Pemeriksaan

\begin{tabular}{|c|c|c|}
\hline Kategori Umur & $\sum$ & $\%$ \\
\hline$\leq 40$ & 33 & $23.91 \%$ \\
\hline$>40$ & 99 & $71.74 \%$ \\
\hline Tidak Tercatat & 6 & $4.35 \%$ \\
\hline$\sum$ & 138 & $100 \%$ \\
\hline
\end{tabular}

Sumber: Data di lapangan, 2019 
Pada Tabel 3. Jumlah peserta berdasarkan kategori umur, peserta terbanyak adalah kelompok umur $>40$ tahun sebanyak 99 orang sedangkan kelompok umur $\leq 40$ tahun sebanyak 33 orang dan yang tidak tercatat sebanyak 6 orang dapat diamati pada Gambar 1. berikut.

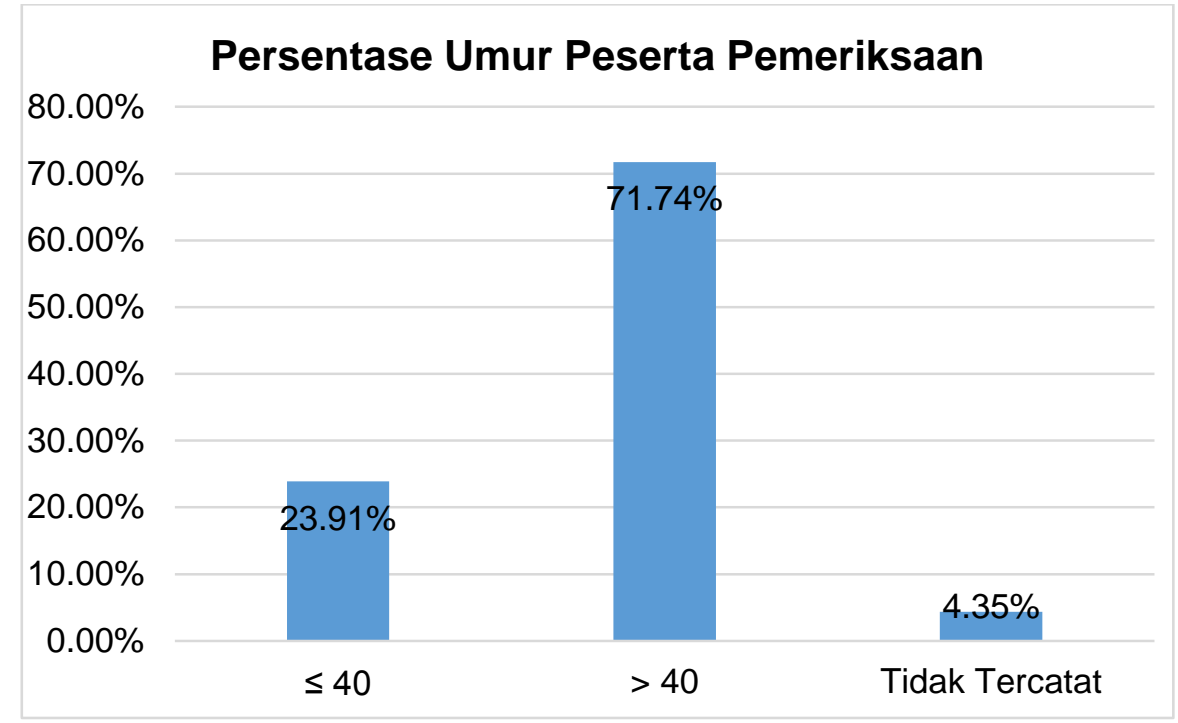

Gambar 1. Grafik jumlah dan kategori umur peserta (Sumber: Data di lapangan, 2019, diolah)

Tabel 4. Persentase Jenis Kelamin Peserta Pemeriksaan

\begin{tabular}{|c|c|c|c|c|c|c|c|c|c|c|}
\hline \multirow{2}{*}{ Peserta } & \multicolumn{10}{|c|}{ RT } \\
\cline { 2 - 12 } & \multicolumn{2}{|c|}{26} & \multicolumn{2}{|c|}{38} & \multicolumn{2}{|c|}{40} & \multicolumn{2}{|c|}{ Lain } & \multicolumn{2}{c|}{ TOTAL } \\
\cline { 2 - 12 } & $\Sigma$ & $\%$ & $\Sigma$ & $\%$ & $\Sigma$ & $\%$ & $\Sigma$ & $\%$ & $\Sigma$ & $\%$ \\
\hline Pria & 13 & $9.42 \%$ & 12 & $8.70 \%$ & 8 & $5.80 \%$ & 6 & $4.35 \%$ & 39 & $\begin{array}{c}28.26 \\
\%\end{array}$ \\
\hline Wanita & 37 & $26.81 \%$ & 27 & $19.57 \%$ & 25 & $\begin{array}{c}18.12 \\
\%\end{array}$ & 10 & $7.25 \%$ & 99 & $\begin{array}{c}71.74 \\
\%\end{array}$ \\
\hline$\Sigma$ & 50 & $36.23 \%$ & 39 & $28.26 \%$ & 33 & $\begin{array}{c}23.91 \\
\%\end{array}$ & 16 & $11.59 \%$ & 138 & $\begin{array}{c}100 \\
\%\end{array}$ \\
\hline
\end{tabular}

Sumber: Data di lapangan, 2019

Pada Tabel 4. Jumlah peserta berdasarkan jenis kelamin, peserta terbanyak adalah peserta dengan jenis kelamin wanita sebanyak 99 orang sedangkan peserta dengan jenis kelamin laki-laki sebanyak 39 orang, dapat diamati pada Gambar 2. berikut. 


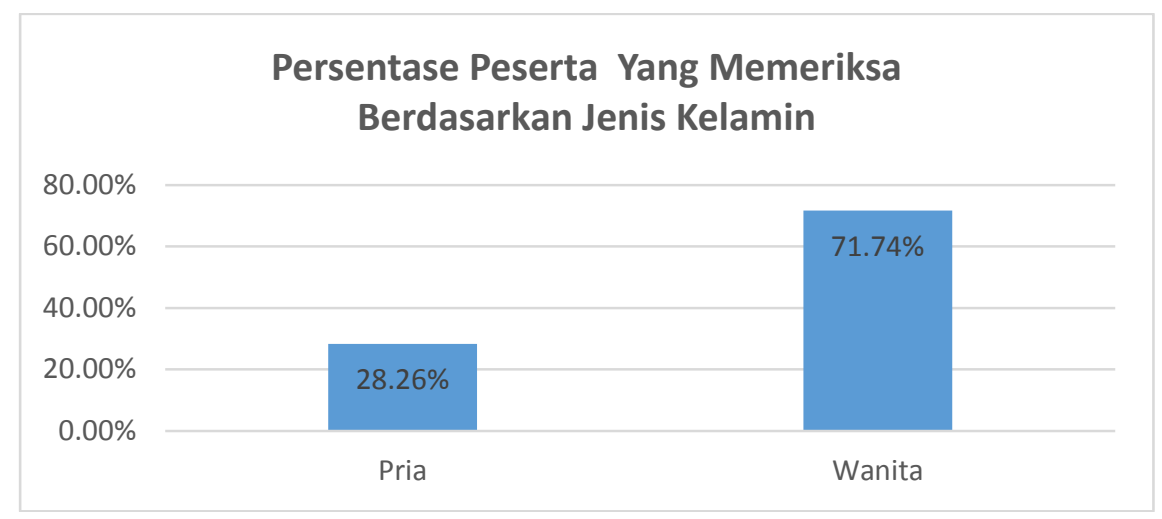

Gambar 2. Grafik Jumlah Dan Kategori Jenis Kelamin Peserta (Sumber: Data di lapangan, 2019, diolah)

Setelah masyarakat berkumpul kami melakukan penyuluhan tentang adanya kenaikkan gula dalam darah dan asam urat pada warga RT 26 , RT 38 dan RT 40 Kelurahan Sukarami Kecamatan Sukarame Kota Palembang serta dampak dari kenaikkan gula darah dan asam urat tersebut serta cara mengatasinya agar terhindar munculnya penyakit. Setelah terjadi diskusi tentang segala hal yang menyangkut dengan kenaikkan glukosa dan kadarasam urat dalam darah didapatkan bahwa seluruh peserta penyuluhan melakukan pemeriksaan dan didapatkan hasil seperti tampak pada tabel berikut :

Tabel 5. Hasil Pengukuran Tekanan Darah

\begin{tabular}{|c|l|l|l|}
\hline No. & Tekanan Darah & Jumlah & Persentase \\
\hline 1 & Normal & 71 & 51,4 \\
\hline 2 & Lebih Dari Normal & 67 & 48,6 \\
\hline \multicolumn{2}{|c|}{ Jumlah } & 138 & $100 \%$ \\
\hline
\end{tabular}

Sumber: Data di lapangan, 2019, diolah

Tabel 5 menunjukkan hasil pengukuran tekanan darah warga yang datang 67 (48,6 \%) lebih normal artinya cukup banyak warga yang cenderung menderita hypertensi. 
Tabel 6. Hasil Pemeriksaan Kadar GlukosaDarah (mg/dl)

\begin{tabular}{|c|c|c|c|c|c|c|c|c|c|c|c|c|c|c|c|c|c|c|}
\hline \multirow{3}{*}{$\begin{array}{l}\text { Kategori } \\
\text { Diabetes }\end{array}$} & \multicolumn{4}{|l|}{26} & \multicolumn{4}{|l|}{38} & \multicolumn{4}{|c|}{40} & \multicolumn{4}{|c|}{ Lain2 } & \multirow{2}{*}{\multicolumn{2}{|c|}{ TOTAL }} \\
\hline & \multicolumn{2}{|c|}{ Pria } & \multicolumn{2}{|c|}{ Wanita } & \multicolumn{2}{|c|}{ Pria } & \multicolumn{2}{|c|}{ Wanita } & \multicolumn{2}{|c|}{ Pria } & \multicolumn{2}{|c|}{ Wanita } & \multicolumn{2}{|c|}{ Pria } & \multicolumn{2}{|c|}{ Wanita } & & \\
\hline & $\Sigma$ & $\%$ & $\Sigma$ & $\%$ & $\Sigma$ & $\%$ & $\Sigma$ & $\%$ & $\Sigma$ & $\%$ & $\Sigma$ & $\%$ & $\Sigma$ & $\%$ & $\Sigma$ & $\%$ & $\Sigma$ & $\%$ \\
\hline $\begin{array}{c}\text { Normal: } \\
<110\end{array}$ & 10 & 7.25 & 30 & 21.74 & 9 & 6.52 & 23 & 16.67 & 5 & 3.62 & 20 & 14.49 & 5 & 3.62 & 9 & 6.52 & 111 & 80.43 \\
\hline $\begin{array}{c}\text { Pra } \\
\text { Diabetes } \\
(110- \\
125)\end{array}$ & 3 & 2.17 & 6 & 4.35 & 3 & 2.17 & 4 & 2.90 & 2 & 1.45 & 1 & 0.72 & 1 & 0.72 & 1 & 0.72 & 21 & 15.22 \\
\hline $\begin{array}{c}\text { Diabetes } \\
:>125\end{array}$ & 0 & 0.00 & 1 & 0.72 & 0 & 0.00 & 0 & 0.00 & 1 & 0.72 & 4 & 2.90 & 0 & 0.00 & 0 & 0.00 & 6 & 4.35 \\
\hline$\Sigma$ & 13 & 9.42 & 37 & $26.81 \%$ & 12 & 8.70 & 27 & 19.57 & 8 & 5.80 & 25 & 18.12 & 6 & 4.35 & 10 & 7.25 & 138 & 100 \\
\hline
\end{tabular}

Sumber: Data di lapangan, 2019, diolah

Pada Tabel 6. dari 138 sampel, pada pemeriksaan dengan hasil kategori normal sebanyak 111 orang, kategori Pradiabetes sebanyak 21 orang dan kategori diabetes sebanyak 6 orang. (Gambar 3).

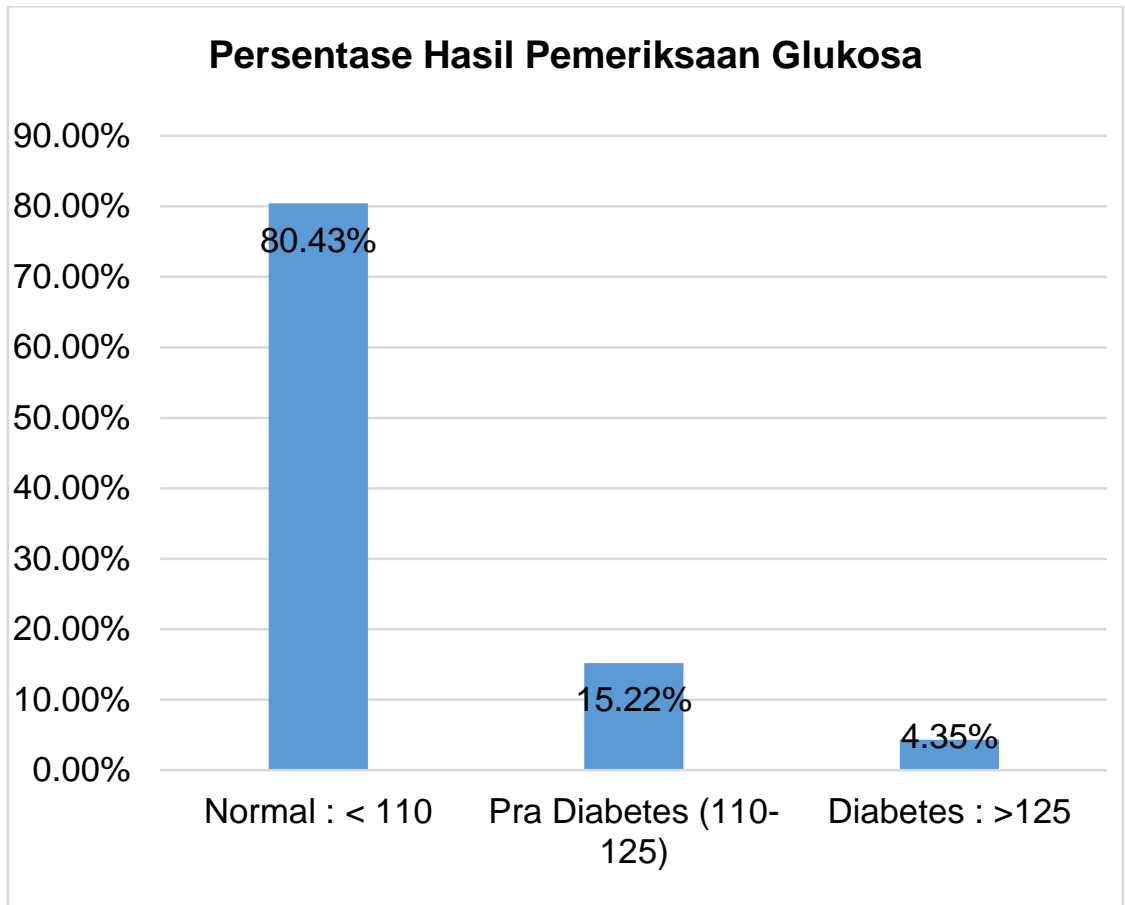

Gambar 3. Grafik Hasil Pemeriksaan Glukosa Dalam Darah (Sumber: Data di lapangan, 2019, diolah) 
Tabel 7. Hasil Pemeriksaan Kadar Asam Urat

\begin{tabular}{|c|c|c|c|c|c|c|c|c|c|c|c|c|c|c|c|c|c|c|}
\hline \multirow{3}{*}{$\begin{array}{l}\text { ASAM } \\
\text { URAT }\end{array}$} & \multicolumn{4}{|l|}{26} & \multicolumn{4}{|l|}{38} & \multicolumn{4}{|l|}{40} & \multicolumn{4}{|l|}{ Lain2 } & \multirow{2}{*}{\multicolumn{2}{|c|}{ TOTAL }} \\
\hline & \multicolumn{2}{|c|}{ Pria } & \multicolumn{2}{|c|}{ Wanita } & \multicolumn{2}{|c|}{ Pria } & \multicolumn{2}{|c|}{ Wanita } & \multicolumn{2}{|c|}{ Pria } & \multicolumn{2}{|c|}{ Wanita } & \multicolumn{2}{|c|}{ Pria } & \multicolumn{2}{|c|}{ Wanita } & & \\
\hline & $\Sigma$ & $\%$ & $\Sigma$ & $\%$ & $\Sigma$ & $\%$ & $\Sigma$ & $\%$ & $\Sigma$ & $\%$ & $\Sigma$ & $\%$ & $\Sigma$ & $\%$ & $\Sigma$ & $\%$ & $\Sigma$ & $\%$ \\
\hline $\begin{array}{l}\text { Normal } \\
:\end{array}$ & 9 & 6.52 & 27 & 19.57 & 10 & 7.25 & 21 & 15.22 & 6 & 4.35 & 21 & 15.22 & 3 & 2.17 & 4 & 2.90 & 101 & 73.19 \\
\hline $\begin{array}{l}\text { Tidak } \\
\text { Normal }\end{array}$ & 4 & 2.90 & 10 & 7.25 & 2 & 1.45 & 5 & 3.62 & 2 & 1.45 & 4 & 2.90 & 3 & 2.17 & 6 & 4.35 & 36 & 26.09 \\
\hline $\begin{array}{l}\text { Tidak } \\
\text { Periksa }\end{array}$ & 0 & 0.00 & 0 & 0.00 & 0 & 0.00 & 1 & 0.72 & 0 & 0.00 & 0 & 0.00 & 0 & 0.00 & 0 & 0.00 & 1 & 0.72 \\
\hline$\Sigma$ & 13 & 9.42 & 37 & 26.81 & 12 & 8.70 & 27 & 19.57 & 8 & 5.80 & 25 & 18.12 & 6 & 4.35 & 10 & 7.25 & 138 & 100 \\
\hline
\end{tabular}

Sumber: Data di lapangan, 2019, diolah

Pada Tabel 7. dari 138 sampel, pada pemeriksaan dengan hasil kategori normal sebanyak 101 orang, kategori tidak normalsebanyak 36 orang dan tidak diperiksa sebanyak 1 orang. (Gambar 4.)

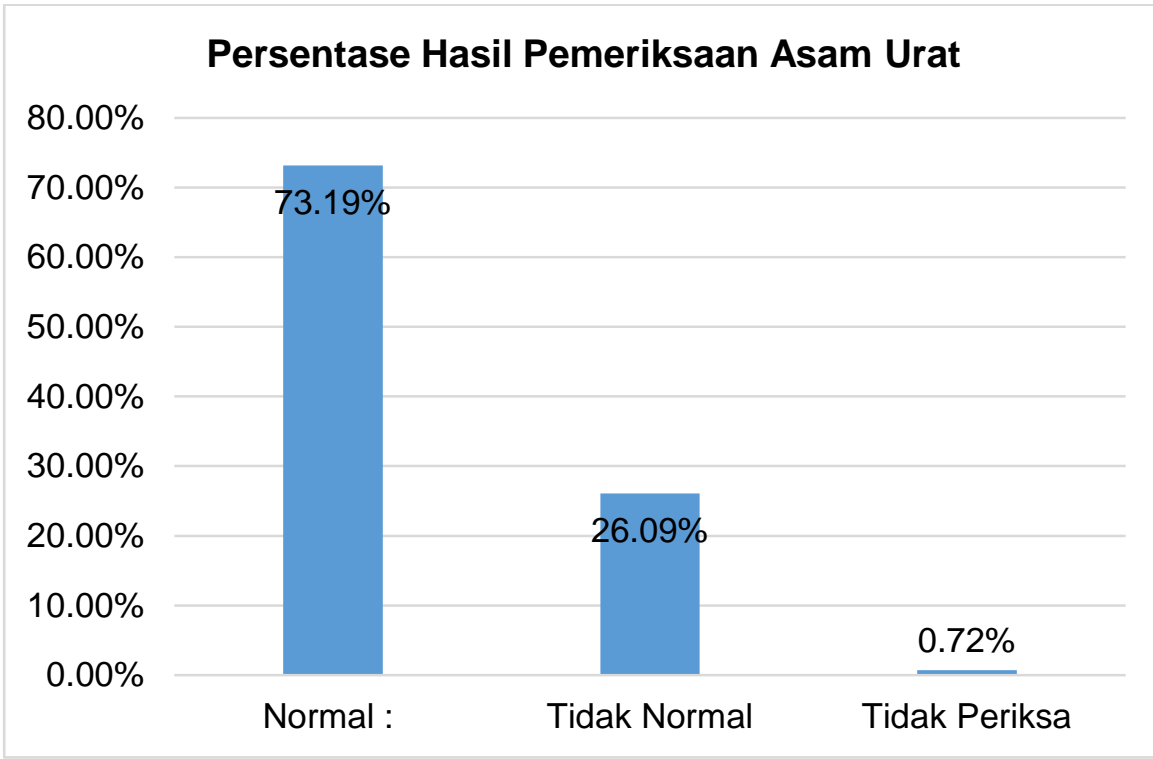

Gambar 4. Grafik Hasil Pemeriksaan Kadar Asam Urat Dalam Darah (Sumber: Data di lapangan, 2019, diolah) 


\section{Diskusi}

Berdasarkan hasil kegiatan PKM yang kami lakukan dari 138 peserta yang mengikuti penyuluhan dan pemeriksaan tentang Edukasi dan Pemeriksaan Darah dalam Rangka Pencegahan Penyakit Menular. Dari 138 jumlah peserta, 33 orang yang berusia $\leq 40$ tahun, 99 orang usia $>40$ tahun, dan 6 orang tidak tercatat. Pada kegiatan PKM menunjukkan hasil pengukuran tekanan darah warga yang datang 67 (48,6 \%) lebih normal artinya cukup banyak warga yang cenderung menderita hypertensi.Hasil rata-rata kadar glukosa darah dalam batas normal sebanyak 111 orang, pradiabetes sebanyak 21 orang, dan yang mengalami diabetes sebanyak 6 orang. Dari 138 peserta, untuk pemeriksaan asam urat yang kadar asam uratnya normal sebanyak 101 orang, kadar asam urat tidak normal sebanyak 36 orang, dan yang tidak diperiksa 1 orang.

Menurut Suyoto (2011) dalam Purwandari.H (2014) mengatakan bahwa gula darah merupakan istilah kesehatan yang menunjuk kepada kandungan gula dalam aliran darah di tubuh, sehingga beresiko terjadinya pradiabetes. Pradiebetes merupakan kondisi dimana kadar gula darah lebih tinggi dari batas normal, namun belum cukup untuk mendiagnosa sebagai diabetes. Bila tidak ditangani dengan baik, kondisi pradiabetes bisa berkembang menjadi diabetes.

Seiring bertambahnya usia seseorang maka terjadi kecenderungan menurunnya berbagai kapasitas fungsional baik pada tingkat seluler maupun pada tingkat organ yang dapat mengakibatkan terjadinya degenerasi sejalan dengan proses menua. Proses menua ini dapat berpengaruh pada perubahan fisiologis yang tidak hanya berpengaruh terhadap penampilan fisik, namun juga terhadap fungsi dan tanggapannya pada kehidupan sehari-hari. Setiap individu mengalami perubahan-perubahan tersebut secara berbeda, ada yang laju penurunannya cepat dan dramatis, serta ada juga yang perubahannya lebih tidak bermakna. Kemunduran sel terjadi pada lanjut usia karena penuaan mengakibatkan kelemahan organ, kemunduran fisik, dan 
timbulnya berbagai penyakit misalnya peningkatan kadar asam urat. 10

Penyakit asam urat atau gout arthritis merupakan suatu penyakit yang diakibatkan karena penimbunan kristal monosodium urat di dalam tubuh. Asam urat adalah hasil metabolisme akhir dari purin, yaitu salah satu komponen asam nukleat yang terdapat dalam inti sel tubuh. Peningkatan kadar asam urat dapat mengakibatkan gangguan pada tubuh seperti perasaan nyeri di daerah persendian. Penumpukan kristal di daerah tersebut disebabkan tingginya kadar asam urat dalam darah. Bahan pangan yang tinggi kandungan purinnya dapatmeningkatkan kadar urat dalam darah antara 0,5 - 0,75 g/ml purin yangdikonsumsi. Konsumsi lemak atau minyak tinggi seperti makanan yangdigoreng, santan, margarin atau mentega dan buah-buahan yang mengandunglemak tinggi seperti durian dan alpukat juga berpengaruh terhadappengeluaran asam urat. 11

Pentingnya mulai mengatur gaya hidup agar terhindar dari segala penyakit sejalan dengan pendapat Pamela RD (2011) dalam Purwandari H (2014) mengatakan bahwa strategi yang dapat dilakukan adalah pengawasan sendiri terhadap berat badan, asupan makanan; mengontrol keinginan untuk makan (motivasi keluarga dan lingkungan seringkali diperlukan dalam hal ini); mengubah perilaku makan dengan mengontrol porsi dan jenis makanan yang dikonsumsi; dan dukungan sosial dari keluarga dan lingkungan.

\section{Simpulan}

Pemeriksaan gula darah dan kadar asam urat dalam darah merupakan kegiatan yang penting dilakukan terutama pada umur $\geq 40$ tahun dimana mulai terjadi perubahan secara fisiologis. Berdasarkan hasil survey warga masyarakatRT 26, RT 38 dan RT 40 Kelurahan Sukarami Kecamatan Sukarame Kota Palembang, pada pemeriksaan gula darah dan asam urat lebih banyak yang normal tetapi hasil pengukuran tekanan darah warga yang

\footnotetext{
${ }^{10}$ Sustrani. Asam Urat. Jakarta; PT. Gramedia Utama, 2009.

${ }^{11}$ Krisnatuti. Perencanaan Menu untuk Penderita Gangguan Asam Urat. Jakarta: Penebar swadaya. 2007.
} 
datangmenunjukkan 67 (48,6 \%) lebih dari normal artinya cukup banyak warga yang cenderung menderita hypertensi. Hal ini dapat disimpulkan bahwa kesadaran warga masyarakat terhadap pentingnya pemeriksaan gula darah dan asam urat terutama bagi usia $>40$ tahun masih perlu pendampingan untuk menyakinkan konsistensi masyarakat terhadap perubahan pola hidup yang sehat dan pemeriksaan darah secara berkala.

\section{Daftar Referensi}

Armaidi Darmawan, 2016,Jurnal, Epidemiologi Penyakit Menular Dan Penyakit Tidak Menular, JMJ, Volume 4, Nomer 2, November 2016

Dina Zakiyyatul Fuadah, Naning Furi Rahayu, 2018, (Jurnal) Pemanfaatan Pos Pembinaan Terpadu (Posbindu) Penyakit Tidak Menular (Ptm) Pada Enderita Hipertensi,Jurnal Ners dan Kebidanan, Volume 5, No. 1, April 2018

Irwan, Dr, SKM, M.Kes, 2016, Epidemiologi Penyakit Tidak Menular,

Kementerian Kesehatan RI, (2017), Pengendalian Penyakit Menular, Direktorat Pengawasan dan pencegahan Penyakit Tidak Menular, Jakarta

Kementerian Kesehatan RI, 2012, Buletin, Penyakit Tidak Menular, Semester II, Jakarta

Krisnatuti. 2007. Perencanaan Menu untuk Penderita Gangguan Asam Urat.Jakarta: Penebar swadaya.

Peraturan Menteri Kesehatan, 2015, Penanggulangan Penyakit TidakMenular, Nomor 1775 tahun 2015

Sustrani. 2009. Asam Urat. Jakarta; PT. Gramedia Utama

Warganegara Efrida dan Nur NN, 2016, Jurnal, Faktor Resiko Prilaku Penyakit Tidak Menular, Mayority, Volume 5, No. 2, April 2016 